Session 1360

\title{
The Current Status of Academic Standards in Engineering Education at Ohio University
}

\author{
Brian Manhire \\ Ohio University
}

\begin{abstract}
Some results are presented from a recent study of academic standards at Ohio University. Findings for both the university and its Russ College of Engineering and Technology are described, contrasted and compared for 1993 and 1999 with due consideration given to the academic caliber of students entering the college and university, as measured by standardized test scores and highschool class standing. Some implications of these findings are described as well as their place within the overall flux of national academic standards in higher education as reported in the literature.
\end{abstract}

\section{Introduction}

The distribution of letter grades awarded for academic achievement in higher education in the United States has changed considerably since the 1960s. Levine and Cureton found that in 1969, 7 percent of students received grades of $A$ - or higher while 25 percent received grades of $C$ or lower and that by 1993 these figures had essentially reversed—becoming 26 percent and 9 percent respectively. ${ }^{1}$ Other reports of changing academic standards (alias grade inflation) have appeared in the literature; $;^{2-25}$ Gibson's recent grade-inflation satire ${ }^{26}$ is indeed indicative of the current academic standards milieu.

These changes are important because acknowledgement of academic achievement has become distorted and this distortion is exacerbated by inconsistent grading standards across the university. In an effort to preserve the traditional cachet of graduating with highest academic achievement, Ohio University responded in 1999 by changing its overall average grade requirement (on a four-point scale) for the honorific summa cum laude from 3.5-4.0 to 3.9-4.0. ${ }^{27}$

In addition, the influence of changing standards extends beyond purely academic considerations. For example, some undergraduate scholarships available to all students at the university (regardless of their major area of study) are based on academic merit, i.e.; grades. Given this award apparatus along with variable grading standards across the university, students majoring in disciplines that grade more generously than others may unfairly benefit financially. ${ }^{27}$

Student fairness and equity issues have a faculty counterpart. There have been nearly two thousand studies of student evaluation of teaching (SET), making this topic perhaps the most extensive area of research in higher education—and there is wide agreement among scholars that SETs 
are a good measure of teaching efficacy. ${ }^{28}$ However, some recent studies cast doubt on the value of SETs and suggest that they foster lower standards (by way of inflated grades) and encourage faculty to dumb-down their courses for reasons pertaining to the impact of SETs on tenure, promotion in rank and salary increases. ${ }^{28-35}$ Apart from conflicting research findings, there is the perception that SETs foster lower standards. 6, 36-39

State governments have increased interest in assessing and controlling the performance of public universities. $^{40-42}$ In Ohio for example, the Ohio Board of Regents has implemented Success Challenge, a program which, through budgetary control, seeks to improve graduation rates for both at-risk students as well as all students at state supported universities in Ohio. ${ }^{43}$ The extension of this sort of budgetary control to academic performance and standards seems plausible ${ }^{44-52}$ given that grade inflation driven grade compression (at the top) coupled with varying standards across campus, make evaluation of candidates for employment and graduate school admission purposes problematic. ${ }^{53}$ In this regard, some state government mandated standardized testing of university students has already begun. ${ }^{54-56}$

Changing academic standards are also important to engineering education, where the role of assessment has recently grown in importance as a result of new accreditation requirements (ABET EC2000). ${ }^{57-58}$ Grades are the linchpin holding student academic performance and program assessment together. As marks of scholastic achievement, grades measure student learning, and as such, they gauge how well academic programs, such as those in the engineering disciplines, succeed in their educational missions.

Grade inflation began during the $1960 \mathrm{~s}^{59-60}$ (Vietnam War ${ }^{61}$ ) and by the 1980 s was built into higher education. ${ }^{4}$ Sacks attributes the continuation of grade inflation beyond the war years to the increasing influence of postmodernism in American society. ${ }^{6}$ Regardless of its causes, grade inflation is ubiquitous and its impact is important.

\section{The Teacher Evaluation of Learning Committee and Its Findings}

In the spring of 2000, Ohio University's central administration commissioned a study of the grade inflation phenomenon at the university. Thus the Teacher Evaluation of Learning Committee (TELC) was formed for this purpose by Ohio University Provost Sharon Stephens Brehm.

In addition to holding discussions and considering testimony, the TELC gathered voluminous undergraduate grade data across many cohorts of the university. Undergraduate grades were collected for the fall quarters (terms) of 1993 and 1999 for the university en masse as well as for the following sectors: the principal academic divisions (colleges) of the university, course levels (i.e., the freshman, sophomore, junior and senior levels), faculty tenure status (i.e., tenured faculty, non-tenured tenure-track faculty and faculty not eligible for tenure) and faculty gender.

The TELC's findings are summarized in a report submitted to the provost in June of $2000 .^{27}$ Here however, only findings for the university's Russ College of Engineering and Technology (RCENT), and for comparison purposes, the university in toto (OU) are presented. 
Undergraduate grade data are shown in table 1. This data was amassed on a per-credit basis to avoid introducing spurious bias into the course-grade descriptive statistics which would result from counting courses carrying different credits equally. ${ }^{62}$ By assembling the data this way, the grade measurements are compatible with the grade-point-average (GPA) calculation widely used in American higher education.

\begin{tabular}{ccccc}
\hline & \multicolumn{2}{c}{ Fall 1993 } & \multicolumn{2}{c}{ Fall 1999 } \\
\hline Grade & RCENT $(\%)$ & OU $(\%)$ & RCENT (\%) & OU (\%) \\
A & 14.73 & 19.89 & 24.27 & 22.68 \\
A- & 11.06 & 12.62 & 13.46 & 13.22 \\
B+ & 12.49 & 11.67 & 13.14 & 12.12 \\
B & 17.03 & 16.28 & 15.70 & 15.78 \\
B- & 10.09 & 8.81 & 7.58 & 8.44 \\
C+ & 7.97 & 6.91 & 5.67 & 6.29 \\
C & 10.75 & 9.47 & 8.45 & 8.49 \\
C- & 3.42 & 4.01 & 2.27 & 3.47 \\
D+ & 2.25 & 2.05 & 1.86 & 1.88 \\
D & 2.87 & 2.97 & 1.98 & 2.68 \\
D- & 1.14 & 1.18 & 0.98 & 1.12 \\
F & 6.20 & 4.16 & 4.64 & 3.82 \\
\hline
\end{tabular}

Table 1. Fall quarter letter-grade percentages, 1993 and 1999

Table 2 tabulates the more coarse whole-letter-grade counterparts $A, B, C, D$ and $F$ formed by aggregating the percentages of each letter grade in table 1 with its \pm gradations, e.g.; where tabulated percentages in table 1 for $B-, B$ and $B+$ are added together to obtain corresponding percentages in the $B$ grade-range category (row) of table 2 .

\begin{tabular}{ccccc}
\hline & \multicolumn{2}{c}{1993} & \multicolumn{2}{c}{1999} \\
\hline Grade & RCENT (\%) & OU (\%) & RCENT (\%) & OU (\%) \\
A & 25.79 & 32.51 & 37.73 & 35.90 \\
B & 39.61 & 36.76 & 36.42 & 36.34 \\
C & 22.14 & 20.39 & 16.39 & 18.25 \\
D & 6.26 & 6.20 & 4.82 & 5.68 \\
F & 6.20 & 4.16 & 4.64 & 3.82 \\
\hline
\end{tabular}

Table 2. Fall quarter whole-letter-grade percentages, 1993 and 1999

RCENT whole-letter-grade percentages for fall 1993 and fall 1999 are shown in figure 1; OU counterpart percentages are shown in figure 2. 


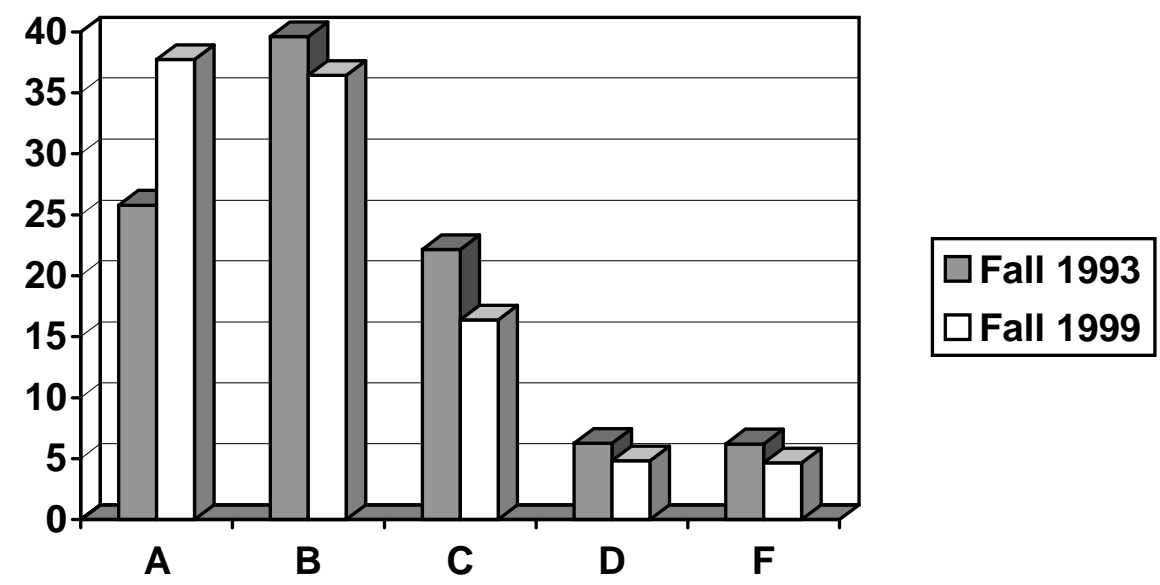

Figure 1. RCENT whole-letter-grade percentages, 1993 and 1999

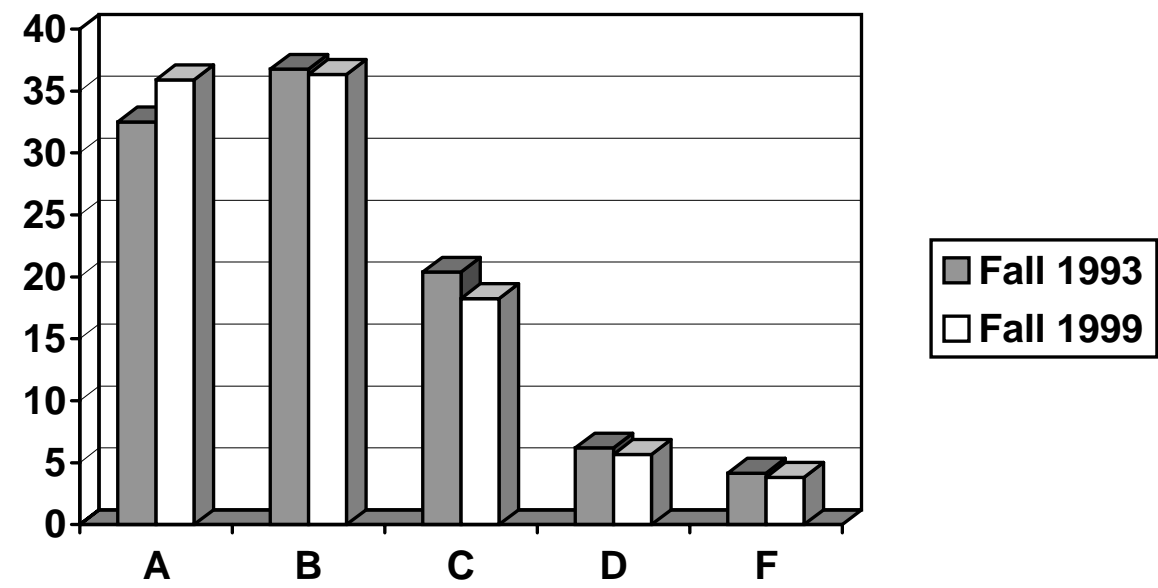

Figure 2. OU whole-letter-grade percentages, 1993 and 1999

The academic aptitude of students was measured by way of SAT and ACT standardized test scores as well as high school class standing and found to be essentially constant over the period $1993-1999 .{ }^{27}$ This finding is consistent with national SAT scores for 1989-1999. ${ }^{63-66}$ The trend of national ACT scores is reported to be steadily increasing since 1990 but flat the past four years. ${ }^{67}$

The following observations are noteworthy. Compared to the academic standards reported by Levine and Cureton ${ }^{1}$ for 1969, grade inflation is evident in both years for both the college and the university with more inflation in 1999 than in 1993. In 1999, grades $A$ - and above total nearly 38 percent for RCENT and nearly 36 percent for the university (table 2), while grades $C$ or lower are roughly 20 percent and 21 percent respectively (table 1). Furthermore, in 1999 the most frequently occurring grade for both RCENT and OU is $A$ (not $A$ and $A$-combined, but $A$ alone). For 1999, these modes are 24.27 percent $A$ for RCENT and 22.68 percent $A$ for OU (table 1 ). 
Within each year, RCENT and OU grade distributions are similar to one another. This suggests that RCENT grading standards and inflation are similar to those for the university en bloc. Grade-point-averages (using numerical weights of 4.0 for $A, 3.0$ for $B, 2.0$ for $C, 1.0$ for $D$ and 0.0 for $F$ ) for the whole-letter-grade histograms for 1999 are 2.98 and 2.95 for RCENT and OU respectively. For 1993, the RCENT and OU histogram GPAs are 2.73 and 2.87 respectively.

The TELC deemed these and other findings unsatisfactory and detrimental to the university's mission. $^{27}$

\section{Recommendation and Conclusion}

Academic standards at Ohio University have been found to be inflated. A valuable next step is to consider them against the backdrop of national standards in order to reasonably and realistically gauge their meaning in the broader national context. Therefore, it is recommended that a national study of academic standards be undertaken under the aegis of perhaps a coalition of suitable organizations. This would provide useful benchmarks against which many colleges and universities could, by performing local studies such as described herein, evaluate their own academic standards situation. In addition, periodic national studies ${ }^{40}$ could foster continuous improvement $^{68-69}$ of academic standards nationally.

The causes of grade inflation are not fully understood. However, some plausible inferences can be drawn from the following facts. In 1900, only about 10 percent of American adolescents aged 14-17 were enrolled in high schools, about 6 percent of teenagers graduated from high school and most of these students were from affluent families. ${ }^{70}$ High school was largely for the children of the elite of American society, i.e.; for the privileged having academic ability. So the spectrum of student demographics, both social and academic, was narrow. At the beginning of the twentieth century, about 2 percent of Americans from the ages of 18 to 24 were enrolled in a college, there were about 1000 colleges then, with enrolment totaling about 157,000. ${ }^{70}$ Around that time, at Ohio University, there were 232 students $^{71}$ in 1897 and 23 faculty $^{72}$ in 1901.

In 1995, 87 percent of Americans between age 25 and 29 had graduated from high school. ${ }^{70}$ Nowadays, more than 60 percent of high school graduates go on to some form of post-secondary education $^{73}$ and there are over 14 million students enrolled in about 4000 four-year and two-year colleges. $^{74}$ So higher education has moved from a former elitist system to the present mass system. Ohio University has followed suit with 28,407 students (total) and 773 full-time faculty (Athens main campus) in $1999 .^{75}$

In his 1997 State of the Union address, President Clinton called for the creation of public policy to enable virtually every high school graduate to receive some form of college education. ${ }^{70}$ The realization of this national goal will move higher education from mass education to universal education - where high school essentially is now, with higher education not too far behind already. 
While this evolution is occurring, quite naturally, the spectrum of student demographics (again both social and academic) is diverging (broadening) to more closely resemble that of present-day American society. ${ }^{10,76-79}$ The phenomenon of grade inflation over the past thirty years or so may be a result of higher education's simultaneous accommodation of the wider spectrum of academic aptitude of the cohort entering the university (consider the issues of remediation, retention and graduation rate for example) while struggling to retain its former elitist ${ }^{80-81}$ values (consider the high interest in quality issues, e.g.; the excellence $e^{82-83}$ that is so commonly expected nowadays by so many stakeholders in all strata of education—so as to render the word a hackneyed cliché, ${ }^{84}$ its meaning having undergone a sort of grade inflation of its own).

As the spectrum of student academic ability has widened, perhaps the traditional distinction awarded to those with the best academic performance is being forfeited by way of grade inflation $^{85-86}$ (through grade compression at the top)—in order for the university to co-opt (graduate) the academically weak that in the earlier elitist era comprised a smaller portion of the student population. ${ }^{80,87}$ In other words, maybe grade inflation is a consequence of conflict between the emerging egalitarian ideal of universal higher education, society's desire to retain the elitist academic standards of an earlier (extinct) era, and its apparently growing belief (misconception) that academic excellence is a commodity the university is able to bestow upon all students regardless of their academic aptitude. ${ }^{88-91}$

In addition, and as mentioned earlier (i.e.; Sacks' hypothesis ${ }^{6}$ ), perhaps the growing influence of postmodernism $^{92-110}$ on American society over the past several decades has contributed to entrenching grade inflation within the zeitgeist of higher education. ${ }^{111-126}$

Whatever its causes, grade inflation is unwholesome. ${ }^{46,127}$ It is hypocritical ${ }^{113,128-129}$ yet its remedy is elusive. . $^{3,20}$ It is beneath the dignity of reputable universities yet it is a longstanding commonplace. As for engineering education at Ohio University, its academic standards are similar to those of the university at large — which are inflated and ipso facto debase the university by, inter alia, nullifying the traditional distinction of high academic achievement. Time will tell how effectively the university will redress the debilitating phenomenon of grade inflation.

References

1. A. Levine and J.S. Cureton, When Hope and Fear Collide: A Portrait of Today's College Student (San Francisco, California: Jossey-Bass, 1998), 125.

2. Murray Sperber, Beer and Circus: How Big-time College Sports Is Crippling Undergraduate Education (New York, New York: Henry Holt and Company, 2000), 118-123, 127-128, 293.

3. Stuart Rojstaczer, Gone for Good: Tales of University Life after the Golden Age (New York, New York: Oxford University Press, 1999), 18-19.

4. Alvin Kernan, In Plato's Cave (New Haven, Connecticut: Yale University Press, 1999), 278-279.

5. Donald Kennedy, Academic Duty (Cambridge, Massachusetts: Harvard University Press, 1997), 79-80.

6. Peter Sacks [pseud.], Generation X Goes to College: An Eye-Opening Account of Teaching In Postmodern America (Chicago, Illinois: Carus Publishing Company, Open Court Publishing Company, 1996), passim.

7. Martin Anderson, Imposters in the Temple (New York, New York: Simon \& Schuster, 1992), 57-60.

8. Charles J. Sykes, ProfScam: Professors and the Demise of Higher Education (Washington, D.C.: Regnery Gateway, 1988), 87. 
9. Allan Bloom, The Closing of the American Mind: How Higher Education Has Failed Democracy and Impoverished the Souls of Today's Students (New York, New York: Simon \& Schuster, Touchstone, 1987), 321, 328, 351.

10. David Riesman, On Higher Education: The Academic Enterprise in an Era of Rising Student Consumerism (San Francisco, California: Jossey-Bass, 1980; reprint, New Brunswick, New Jersey: Transaction Publishers, 1998), 76-81 (page citations are to the reprint edition).

11. Kenneth H. Ashworth, American Higher Education in Decline (College Station, Texas: Texas A\&M University Press, 1979), 54.

12. A. Sanderson, V. C. Phua and D. Herda, The American Faculty Pole (Chicago, Illinois: National Opinion Research Center, 2000), 39. URL: http://www.norc.uchicago.edu/online/tiaa-fin.htm

13. R. Eric Landrum, "Student Expectations of Grade Inflation," Journal of Research and Development in Education, Vol. 32, No. 2, 1999, 124-128.

14. Stephanie Mc Spirit and Kirk E. Jones, "Grade Inflation Rates Among Different Ability Students, Controlling for Other Factors," Educational Policy Analysis Archives, Vol. 7, No. 30, September 1999, ISSN 1068-2341. URL: http://olam.ed.asu.edu/epaa/v7n30.html

15. William Beaver, "Declining College Standards: It's Not the Courses, It's the Grades," The College Board Review, No. 181, July 1997, 2-7.

16. Henry Cohen, "Inflated Grades, Deflated Courses: Has Insecurity Induced Compromise?," Change, May/June 1984, 8-10.

17. William Cole, "The Perils of Grade Inflation," The Chronicle of Higher Education, 6 January 1993.

URL: http://chronicle.com/che-data/articles.dir/articles-39.dir/issue-18.dir/18b00101.htm

18. Craig A. Lambert, "Desperately Seeking Summa," Harvard Magazine, May-June 1993, 36-40.

19. Christopher Shea, "The Subtleties of Grade Inflation," The Chronicle of Higher Education, 5 January 1994. URL: http://chronicle.com/che-data/articles.dir/articles-40.dir/issue-18.dir/18a04501.htm

20. Ben Gose, "Efforts to Curb Grade Inflation Get an F From Many Critics," The Chronicle of Higher Education, 25 July 1997. URL: http://chronicle.com/che-data/articles.dir/art-43.dir/issue-46.dir/46a00101.htm

21. Lee Clark Mitchell, "Inflation Isn't the Only Thing Wrong With Grading," The Chronicle of Higher Education, 8 May 1998, A72. URL: http://chronicle.com/che-data/articles.dir/art-44.dir/issue-35.dir/35a07201.htm

22. David Altstadt, "Grades on the Rise," The Post, 7 May 1999, 6.

URL: http://thepost.baker.ohiou.edu/archives2/050799/601.html

23. J. Linn Allen, "A's Near Par for Course in College," The Chicago Tribune, 28 April 2000, 1. URL: http://chicagotribune.com/news/printedition/article/0,2669,SAV-0004280175,FF.html

24. Jennifer Yachnin, "A Grading Curve Flunks Out," The Chronicle of Higher Education, 9 February 2001, A8. URL: http://chronicle.com/weekly/v47/i22/22a00803.htm

25. Alison Schneider, "What Grade Would You Give Him?," The Chronicle of Higher Education, 16 February 2001, A10. URL: http://chronicle.com/weekly/v47/i23/23a01001.htm, also see URL: http://chronicle.com/daily/2001/02/2001020603n.htm

26. William Gibson, "A Modest A++ Proposal for a Solution to the Problem of Grade Inflation," The Journal of Irreproducible Results, Vol. 45, No. 1, 2000, 12-13.

27. Teacher Evaluation of Learning Committee Report of Spring Quarter 2000, Ohio University, June 2000. URL: http://www.ohiou.edu/apaa/SETandTELreport.doc

28. Robin Wilson, "New Research Casts Doubt on Value of Student Evaluations of Professors," The Chronicle of Higher Education, 16 January 1998.

URL: http://chronicle.com/che-data/articles.dir/art-44.dir/issue-19.dir/19a01201.htm

29. Randal C. Archibald, "Payback Time: Give Me an 'A' or Else," The New York Times, 24 May 1998.

URL: http://www.nytimes.com/library/review/052498students-evaluate-review.html

30. A. G. Greenwald, "Validity concerns and usefulness of student ratings," American Psychologist, 52, 1997, $1182-1186$.

31. A. G. Greenwald and G. M. Gillmore, "Grading leniency is a removable contaminant of student ratings," American Psychologist, 52, 1997, 1209-1217.

32. A. G. Greenwald and G. M. Gillmore, "No pain, no gain? The importance of measuring course workload in student ratings of instruction," Journal of Educational Psychology, 89, 1997, 743-751.

33. Ted Marchese, "Student Evaluations of Teaching," Change, September/October 1997, 4.

34. Wendy M. Williams and Stephen J. Ceci, "How'm I Doing?: Problems With Student Ratings of Instructors and Courses," Change, September/October 1997, 13-23. 
35. Anthony C. Krautmann and William Sander, "Grades and student evaluations of teachers," Economics of Education Review, 18, 1999, 59-63.

36. Ben Marcus, "Graded by My Students," Time, 8 January 2001, 51. URL: http://www.time.com/time/magazine/article/0,9171,93296,00.html

37. Paul Trout, "Flunking the Test: The Dismal Record of Student Evaluations," Academe, Vol. 86, No. 4, JulyAugust 2000, 58-61. URL: http://www.aaup.org/JA00Trou.htm

38. Paul Trout, "Low Marks for Top Teachers," The Washington Post, 13 March 2000, A17. URL: $\underline{\text { http://www.bus.lsu.edu/accounting/faculty/lcrumbley/lowmarks.html }}$

39. Emily Toth, Ms. Mentor's Impeccable Advice for Women in Academia (Philadelphia, Pennsylvania: University of Pennsylvania Press, 1997), 77-78, 94-96.

40. Measuring Up 2000: The State-By-State Report Card for Higher Education (Washington, D.C.: The National Center for Public Policy and Higher Education, 2000), passim. URL: http://measuringup2000.highereducation.org/

41. Joseph C. Burke and Shahpar Modarresi, "To Keep or Not to Keep Performance Funding: Signals from Stakeholders," Journal of Higher Education, Vol. 71, No. 4, July/August 2000, 432-453.

42. Robert Birnbaum, Management Fads in Higher Education: Where They Come From, What They Do, Why They Fail (San Francisco, California: Jossey-Bass, 2000), 85-89.

43. URL: http://www.regents.state.oh.us/hei/success/successchallenge.html

44. Ernest L. Boyer, "Measuring the Outcome," in College: The Undergraduate Experience in America (New York, New York: Harper \& Row, Perennial Library, 1987), 251-263.

45. Ashworth, American Higher Education in Decline, 70.

46. Louis Goldman, "The Betrayal of the Gatekeepers: Grade Inflation," The Journal of General Education, Vol. 37, No. 2, 1985, 97-121.

47. Christopher J. Lucas, Crisis In The Academy: Rethinking Higher Education In America (New York, New York: St. Martin's Press, Griffin edition, 1996), 35-37.

48. Robert Holyer, "The Road Not Taken," Change, September/October 1998, 41-43.

URL: http://www.aahe.org/change/so982.htm

49. Paul Trout, "Testing Undergraduate Education," The Montana Professor, Vol. 10, No. 2, Spring 2000, 13-18. URL: http://mtprof.msun.edu/Spr2000/Trout.html

50. Sperber, Beer and Circus, 266-267.

51. Joseph C. Burke, Shahpar Modarresi and Andreea M. Serban, "Performance: Shouldn't It Count for Something in State Budgeting?," Change, November/December 1999, 17-23.

52. F. King Alexander, "The Changing Face of Accountability: Monitoring and Assessing Institutional Performance in Higher Education," Journal of Higher Education, Vol. 71, No. 4, July/August 2000, 411-431.

53. Nicholas Lemann, "The Declining Significance of Grades," New Yorker Magazine, 3 April 2000, 27-28.

54. Ted Marchese, "Assessment and Standards," Change, September/October 1998, 4.

55. Peter Schmidt, "Faculty Outcry Greets Proposal for Competency Tests at U. of Texas," The Chronicle of Higher Education, 6 October 2000, A35. URL: http://chronicle.com/weekly/v47/i06/06a03501.htm

56. Peter Ewell, "Grading Student Learning: Better Luck Next Time," in Measuring Up 2000, 174-176.

57. Trudy E. Bell, "Proven skills: the new yardstick for schools," IEEE Spectrum, Vol. 37, No. 9, September 2000, 63-67. URL: http://www.spectrum.ieee.org/publicfeature/sep00/abet.html, also see URL: http://www.abet.org/

58. Jane V. Wellman, "Accreditors Have to See Past 'Learning Outcomes'," The Chronicle of Higher Education, 22 September 2000, B20. URL: http://chronicle.com/weekly/v47/i04/04b02001.htm

59. Allan Bloom, "The Sixties," in Closing of the American Mind, 313-335.

60. David Riesman, "The Rise of Student Disaffection," in On Higher Education, 65-104.

61. Kernan, In Plato's Cave, 173.

62. Cooper B. Holmes, The Honest Truth About Lying With Statistics (Springfield, Illinois: Charles C. Thomas, Publisher, 1990), passim.

63. William H. Honan, "S.A.T. Scores Decline as Grades Rise," The New York Times, 2 September 1998, B8.

64. Scott Carlson, "College Board Reports Little Change in Average SAT Scores," The Chronicle of Higher Education, 10 September 1999. URL: http://chronicle.com/weekly/v46/i03/03a05601.htm

65. Ben Wildavsky, "At least they have high self-esteem," U.S. News \& World Report, 7 February 2000, 50. URL: http://www.usnews.com/usnews/issue/000207/ucla.htm

66. Ronald Rutti, "Grade inflation makes all kids above average, college officials find," The Cleveland Plain Dealer, 21 February 2000, 1A. URL: http://www.ohioroundtable.org/library/articles/ed/gradeinflation.html

Proceedings of the 2001 American Society for Engineering Education Annual Conference \& Exposition Copyright (C) 2001, American Society for Engineering Education 
67. Leo Reisberg, "Average ACT Score Holds Steady at 21; Record Number of Seniors Take the Test," The Chronicle of Higher Education, 17 August 2000.

68. Birnbaum, Management Fads in Higher Education, 91-108.

69. Robert Birnbaum, "The Life Cycle of Academic Management Fads," Journal of Higher Education, Vol. 71, No. 1, January/February 2000, 1-16.

70. Microsoft Encarta DVD-ROM Reference Suite 99 (Redmond, Washington: Microsoft Corporation, 1999).

71. Thomas N. Hoover, The History of Ohio University (Athens, Ohio: Ohio University Press, 1954), 177.

72. Ibid., 194.

73. Arthur Levine, "How the Academic Profession is Changing," Daedalus (Journal of the American Academy of Arts and Sciences, issued as Proceedings of the American Academy of Arts and Sciences: The American Academic Profession), Vol. 126, No. 4, Fall 1997, 1-20.

74. The Chronicle of Higher Education Almanac Issue, Vol. XLVI, No. 1, August 1999, 7. URL: http://chronicle.com/free/almanac/1999/almanac.htm

75. Ohio University Fact Card, Ohio University Publications (5646-10M), 1999.

76. Annette Kolodny, Failing the Future: A Dean Looks at Higher Education in the Twenty-first Century (Durham, North Carolina: Duke University Press, 1998), 34.

77. Lucas, Crisis In The Academy, 204-205.

78. Ashworth, American Higher Education in Decline, 58, 104.

79. James Lee, "OU should look at how other institutions have dealt with grade inflation," The Athens NEWS, 18 December 2000, 5. URL: http://www.athensnews.com/

80. William A. Henry III, "The Museum of Clear Ideas," in In Defense of Elitism, (New York, New York: Doubleday, Anchor Books, 1994), 149-168.

81. George F. Will, "D is for Dodo," Newsweek, 9 February 1976, 84.

82. Birnbaum, Management Fads in Higher Education, 7-8.

83. Bill Readings, The University in Ruins (Cambridge, Massachusetts: Harvard University Press, 1996), passim.

84. Ibid., 12.

85. Riesman, On Higher Education, 81.

86. Janet W. Wohlberg, "Grade Inflation Demeans Good Students," The New York Times, 7 July 1995, A24.

87. Sykes, ProfScam, 85-87.

88. David F. Labaree, How To Succeed In School Without Really Trying: The Credentials Race in American Education (New Haven, Connecticut: Yale University Press, 1997), 21, 32, 44-50.

89. Maureen Stout, The Feel-Good Curriculum: The Dumbing-Down of America's Kids in the Name of SelfEsteem (Cambridge, Massachusetts: Perseus Books, 2000), 208-212.

90. Samuel G. Freedman, "Consumer demand inflates grades," USA TODAY, 17 May 2000, 15A.

91. Kurt Wiesenfeld, "Making the Grade," Newsweek, 17 June 1996, 16.

92. Chris Rohmann, A World of Ideas: A Dictionary of Important Theories, Concepts, Beliefs, and Thinkers (New York, New York: Random House, Ballantine Books, 1999), 310-311.

93. Alvin Kernan, "Question All Authority: The Breakdown of Meaning and Language, Yale, 1970-1973," in In Plato's Cave, 179-201.

94. Alvin Kernan, The Death of Literature (New Haven, Connecticut: Yale University Press, 1990), passim.

95. John M. Ellis, Literature Lost: Social Agendas and the Corruption of the Humanities (New Haven, Connecticut: Yale University Press, 1997), passim.

96. John M. Ellis, Against Deconstruction (Princeton, New Jersey: Princeton University Press, 1989), passim.

97. Mark Bauerlein, Literary Criticism: An Autopsy (Philadelphia, Pennsylvania: University of Pennsylvania Press, 1997), passim.

98. Paul R. Gross and Norman Levitt, Higher Superstition: The Academic Left and Its Quarrels with Science (Baltimore, Maryland: The Johns Hopkins University Press, 1994), passim.

99. Evelyn Fox Keller, "Science and Its Critics," in The Future of Academic Freedom, ed. Louis Menand, (Chicago, Illinois: The University of Chicago Press, 1996), 199-213.

100. Noretta Koertge ed., A House Built on Sand: Exposing Postmodern Myths About Science, (New York, New York: Oxford University Press, 1998), passim.

101. Alan D. Sokal and Jean Bricmont, Fashionable Nonsense: Postmodern Intellectuals' Abuse of Science (New York, New York: St. Martin's Press, Picador USA, 1998), passim.

102. Alan D. Sokal, "A Physicist Experiments with Cultural Studies," Lingua Franca, May/June 1996, 62-64. URL: $\underline{\text { http://www.linguafranca.com/9605/sokal.html }}$ 
103. The editors of Lingua Franca eds., The Sokal Hoax: The Sham That Shook the Academy (Lincoln, Nebraska: University of Nebraska Press, 2000), passim.

104. Linda Ray Pratt, "Liberal Education and the Idea of the Postmodern University," Academe, Vol. 80, No. 6, November-December 1994, 46-51.

105. Sykes, ProfScam, 181-187.

106. Charles J. Sykes, The Hollow Men: Politics and Corruption in Higher Education (Washington, D.C.: Regnery Gateway, 1990), 28.

107. Richard M. Huber, How Professors Play the Cat Guarding the Cream: Why We're Paying More and Getting Less in Higher Education (Fairfax, Virginia: George Mason University Press, 1992), 42-48.

108. Alan Charles Kors and Harvey A. Silverglate, The Shadow University: The Betrayal of Liberty on America's Campuses (New York, New York: Simon \& Schuster Inc., The Free Press, 1998), 152.

109. Bloom, Closing of the American Mind, 379-380.

110. Birnbaum, Management Fads in Higher Education, 225-226.

111. Noretta Koertge, "Postmodernisms and the Problem of Scientific Literacy," in House Built on Sand, $257-271$.

112. Sokal and Bricmont, "Epilogue," in Fashionable Nonsense, 182-211.

113. Bradford P. Wilson, "The Phenomenon of Grade Inflation in Higher Education," National Forum (Phi Kappa Phi Journal), Vol. 79, No. 4, Fall 2000, 38-41. URL: http://www.nas.org/press.html

114. Mary Burgan, "Making the Grade," Academe, Vol. 86, No. 6, November-December 2000, 80.

115. Anne Matthews, Bright College Years: Inside the American Campus Today (New York, New York: Simon \& Schuster Inc., 1997), 205-206.

116. Glenn C. Altschuler, "Let Me Edutain You," The New York Times, Education Life Supplement, 4 April 1999, 50.

117. Ted Marchese, "Disengaged Students," Change, March/April 1998, 4.

118. Ted Marchese, "Disengaged Students II," Change, May/June 1998, 4.

119. Arthur Levine and Jeanette S. Cureton, "Collegiate Life: An Obituary," Change, May/June 1998, $12-17,51$.

120. Mark Edmundson, "On the Uses of a Liberal Education: I. As Lite Entertainment for Bored College Students," Harper's Magazine, September 1997, 39-49. URL: http://scs.student.virginia.edu/ decweb/lite/

121. William R. Beaver, "Cheapening College," American Outlook, Summer 2000, 43-44.

122. Keith H. Hammonds et al., "The New University," Business Week, 22 December 1997, 96-102. URL: http://www.businessweek.com/common_frames/bws.htm?http://www.businessweek.com/1997/51/b3558139.htm

123. Eyal Press and Jennifer Washburn, "The Kept University," The Atlantic Monthly, March 2000, 39-54. URL: http://www.theatlantic.com/issues/2000/03/press.htm

124. Cary Nelson and Stephen Watt, "The Corporate University," in Academic Keywords: A Devil's Dictionary for Higher Education, (New York, New York: Routledge, 1999), 84-98.

125. Frank Newman, "Saving Higher Education's Soul," Change, September/October 2000, 16-23. URL: http://www.brown.edu/Departments/Taubman_Center/Futures_Project/images/Soul.doc

126. Morris Berman, The Twilight of American Culture (New York, New York: W. W. Norton \& Company, Inc., 2000), 33-52, 121-128.

127. James B. Twitchell, For Shame: The Loss of Common Decency in American Culture (New York, New York: St. Martin's Press, 1997), dj, 13-14, 154-169.

128. James R. Otteson, "Grade Inflation and the John Wayne Teacher," The Montana Professor, Vol. 7, No. 1, Winter 1997, 21-22. URL: http://mtprof.msun.edu/Win1997/Otteson.html

129. James B. Twitchell, "Stop Me Before I Give Your Kid Another 'A'," The Washington Post, 4 June 1997, A23.

\section{BRIAN MANHIRE}

Brian Manhire (manhire@ ohio.edu, http://www.ent.ohiou.edu/ manhire/) is a professor of electrical engineering at Ohio University. 